\title{
Rapid and sensitive detection of Citrus Bacterial Canker by loop-mediated isothermal amplification combined with simple visual evaluation methods
}

\author{
Luciano A Rigano1, María R Marano², Atilio P Castagnaro³, Alexandre Morais Do Amaral4 and Adrian A Vojnov*1
}

\begin{abstract}
Background: Citrus Bacterial Canker (CBC) is a major, highly contagious disease of citrus plants present in many countries in Asia, Africa and America, but not in the Mediterranean area. There are three types of Citrus Bacterial Canker, named $A, B$, and $C$ that have different genotypes and posses variation in host range within citrus species. The causative agent for type A CBC is Xanthomonas citri subsp. citri, while Xanthomonas fuscans subsp. aurantifolii, strain B causes type B CBC and Xanthomonas fuscans subsp. aurantifolii strain C causes CBC type $C$. The early and accurate identification of those bacteria is essential for the protection of the citrus industry. Detection methods based on bacterial isolation, antibodies or polymerase chain reaction (PCR) have been developed previously; however, these approaches may be time consuming, laborious and, in the case of PCR, it requires expensive laboratory equipment. Loop-mediated isothermal amplification (LAMP), which is a novel isothermal DNA amplification technique, is sensitive, specific, fast and requires no specialized laboratory equipment.
\end{abstract}

Results: A loop-mediated isothermal amplification assay for the diagnosis of Citrus Bacterial Canker (CBC-LAMP) was developed and evaluated. DNA samples were obtained from infected plants or cultured bacteria. A typical ladder-like pattern on gel electrophoresis was observed in all positive samples in contrast to the negative controls. In addition, amplification products were detected by visual inspection using SYBRGreen and using a lateral flow dipstick, eliminating the need for gel electrophoresis. The sensitivity and specificity of the assay were evaluated in different conditions and using several sample sources which included purified DNA, bacterium culture and infected plant tissue. The sensitivity of the CBC-LAMP was $10 \mathrm{fg}$ of pure XCC DNA, 5 CFU in culture samples and 18 CFU in samples of infected plant tissue. No cross reaction was observed with DNA of other phytopathogenic bacteria. The assay was capable of detecting CBC-causing strains from several geographical origins and pathotypes.

Conclusions: The CBC-LAMP technique is a simple, fast, sensitive and specific method for the diagnosis of Citrus Bacterial Canker. This method can be useful in the phytosanitary programs of the citrus industry worldwide.

\section{Background}

Citrus Bacterial Canker is an economic important disease in several countries, and causes great losses in fruit production and its subsidiaries [1]. There are three types of Citrus Bacterial Canker identified that have different genotypes and posses variations in host range among citrus plants. The type A CBC originating from Asia, is caused by Xanthomonas citri subsp. citri, this is the most

\footnotetext{
* Correspondence: avojnov@fundacioncassara.org.ar

1 Instituto de Ciencia y Tecnología Dr. Cesar Milstein, Fundación Pablo Cassará, Consejo Nacional de Investigaciones Científicas y Técnicas, Saladillo 2468, Ciudad de Buenos Aires, Argentina

Full list of author information is available at the end of the article
}

destructive and widespread variant of the disease with a host range that includes all citrus cultivars [2]. The CBC types B and C are caused by Xanthomonas fuscans subsp. aurantifolii strains B and C, respectively. Those bacteria are limited in host range and are geographically restricted to South America. Type B CBC is present only in Argentina, Uruguay and Paraguay and is found primarily on lemon and orange [2]. Type C CBC is limited to the Sao Paulo state in Brazil and infects key or mexican lime [2]. The symptoms induced by the tree forms of canker organisms are similar and consist of cankers surrounded by chlorotic haloes and surface necrotic lesions on fruits or leaves and water-soaked lesions on leaves. Besides its 
leaf symptoms, this disease can cause early fruit abscission and general tree decline and the infected fruit lose market price. Moreover, quarantine restrictions are applied to prevent the spread of the pathogen to new areas, which limit drastically the trade of fresh citrus fruit with the consequent economic damage [3]. Those quarantine programs consist of rapid and reliable detection of the bacteria in all the sampled material, which include seedlings, fruits and leaves. Currently, the main procedure to detect infection is visual inspection based on disease symptoms on trees. Samples that are suspected to be positive are sent to diagnostic laboratories for further isolation on culture media. These cultures are used for reinoculation on citrus and for detection by serological methods [4]. Methodologies based on the culture of the bacterium are laborious and time consuming. In another approach, polymerase chain reaction is used for the detection of $X c c$ using different genomic portions as amplification targets [5-7]. These methods are more sensitive, specific and faster than the methods based on bacterial culture, however require modern and expensive laboratory facilities and can be difficult to perform, depending on the location. In addition, they require the use of gel electrophoresis to detect amplified products, which is long and tedious. Real-time PCR assays developed for the rapid detection of Xcc $[4,8]$ have the drawback of requiring an expensive thermal cycler with a fluorescence detector.

Loop-mediated isothermal amplification (LAMP) is a recent DNA amplification technique that amplifies DNA with high specificity, efficiency and rapidity under isothermal conditions [9]. LAMP is based on the principle of autocycling strand displacement DNA synthesis performed by the Bst DNA polymerase, for the detection of a specific DNA sequence [9]. The technique uses four to six primers that recognize six to eight regions of the target DNA and provides very high specificity $[9,10]$. The technique can be carried out under isothermal conditions ranging between 60 and $65^{\circ} \mathrm{C}$ and produces large amounts of DNA [9]. The reaction shows high tolerance to biological contaminants [11], which can help to avoid false negative results due to the inactivation of the enzyme, a common problem in PCR. Although LAMP amplification products can also be detected by gel electrophoresis, this long procedure reduces the suitability for field applications. For this reason we used SYBRGreen I, an intercalating DNA dye, and a generic lateral flow dipstick (LFD) device to detect the positive amplification by simple visual inspection, as described previously [1220], with potential field application. We optimized the assay for the amplification of a portion of the $p t h A$ gene, a well known pathogenicity determinant of $\mathrm{CBC}$-causing Xanthomonas [21-25]. Various LAMP assays for the detection of animal and human pathogens have been developed [20,26-33], but this technique remains uncommon for bacterial plant pathogens. Here we describe a sensitive, specific, fast, and simple LAMP assay for the detection of Citrus Bacterial Canker.

\section{Results}

Reaction conditions were optimized to establish fast and efficient parameters for amplification. Different temperatures, times and the use of loop primers, which have the capacity to accelerate the reaction, were tested [10]. The optimal amplification of the $p t h A$ gene fragment was obtained at $65^{\circ} \mathrm{C}$ for $30 \mathrm{~min}$ using loop primers, as shown by agarose gel electrophoresis (Fig. 1). Amplified products exhibited a typical ladder-like pattern. No products were observed in negative control without DNA (Fig. 1). Specificity of the amplification product was confirmed by sequencing of some bands (data not shown). The samples giving positive reaction show a green color with the addition of SYBRGreen I, while the negative control remained orange (Fig. 2). The lateral flow dipstick shows two clear lines for the positive reaction (the lower line is the sample assay band and the upper one is the control line) while the negative reaction shows only the control line (Fig. 2). CBC-LAMP assays carried out using purified DNA from other common citrus and plant pathogens gave no amplification as evidenced by gel electrophoresis, SYBRGreen stain or LFD (Table 1).

The CBC-LAMP detection limit was determined using Xanthomonas citri subsp. citri strain 306. The detection limit for Xcc pure DNA was $10 \mathrm{fg}$ (Table 2), 5 CFU of Xcc cultured cells and $18 \mathrm{CFU}$ from infected leave tissues according to the detection method used (Table 3). Positive amplification was obtained for every $\mathrm{CBC}$-causing Xanthomonas strains from different regions in Argentina and around the world, including $\mathrm{CBC}$ types $\mathrm{A}, \mathrm{B}$ and $\mathrm{C}$ strains. Xanthomonas axonopodis pv. citrumelo, the causative agent of Citrus Bacterial Spot, a non canker producing citrus associated bacteria, did not produced any amplification (Table 4).

The potential use of this technique in location was evaluated. Infected lemon and orange fruits and leaves were collected in field. All the field samples with canker symptoms gave positive reaction using all amplicon detection methods presented in this work (Additional file $1 \mathrm{fig}$. S1).

\section{Discussion}

Citrus Bacterial Canker is a serious, aggressive disease that attacks most species of citrus worldwide. Rapid and correct diagnosis of the pathogens is crucial to minimize and control damage to the citrus industry. During the last decade several nucleic acid amplification-based methods have been developed for the detection of CBC causingXanthomonas [4-8]. These methods are fast, specific and sensitive, but are not applicable for field trials, since they 
Table 1: Specificity of CBC-LAMP assay

\begin{tabular}{|c|c|c|c|c|}
\hline \multirow[t]{2}{*}{ Species } & \multirow[t]{2}{*}{ Strain } & \multicolumn{3}{|c|}{ Detection Method } \\
\hline & & Gel & LFD & SYBRGreen \\
\hline Xanthomonas citri subsp. citri & 306 & + & + & + \\
\hline Xylella fastidiosa & $9 a 5 c$ & - & - & - \\
\hline Candidatus Liberibacter asiaticus & * & - & - & - \\
\hline Xanthomonas campestris pv. campestris & 8004 & - & - & - \\
\hline Xanthomonas campestris pv. vesicatoria & $85-10$ & - & - & - \\
\hline Pseudomonas syringae & DC3000 & - & - & - \\
\hline Botrytis cinerea & B-191 & - & - & - \\
\hline Phytophthora citricola & * & - & - & - \\
\hline Guignardia citricarpa & * & - & - & - \\
\hline Elsinoe fawcettii & * & - & - & - \\
\hline
\end{tabular}

For each dilution CBC-LAMP reaction was performed in triplicate. Gel: gel electrophoresis. LFD: lateral flow dipstick.+: Positive reaction.: Negative reaction. * Performed with DNA from an infected plant without symptoms of CBC.

can require equipment and facilities that are not easily portable. The methodology presented in this work demonstrated that $\mathrm{CBC}$ can be detected quickly, sensitively and specifically by using LAMP technology in an equipment-free procedure. The use of gene $p t h A$ was proven to be very selective and efficient for the diagnosis of $C B C$ as it has been described previously $[4,6,8]$. Our studies suggest that the sensitivity could be greater than in those achieved previously by conventional PCR [5,7] and comparable to those reported by using real-time PCR [4], although a comparative study must be performed to confirm it. On the other hand, the high sensitivity observed

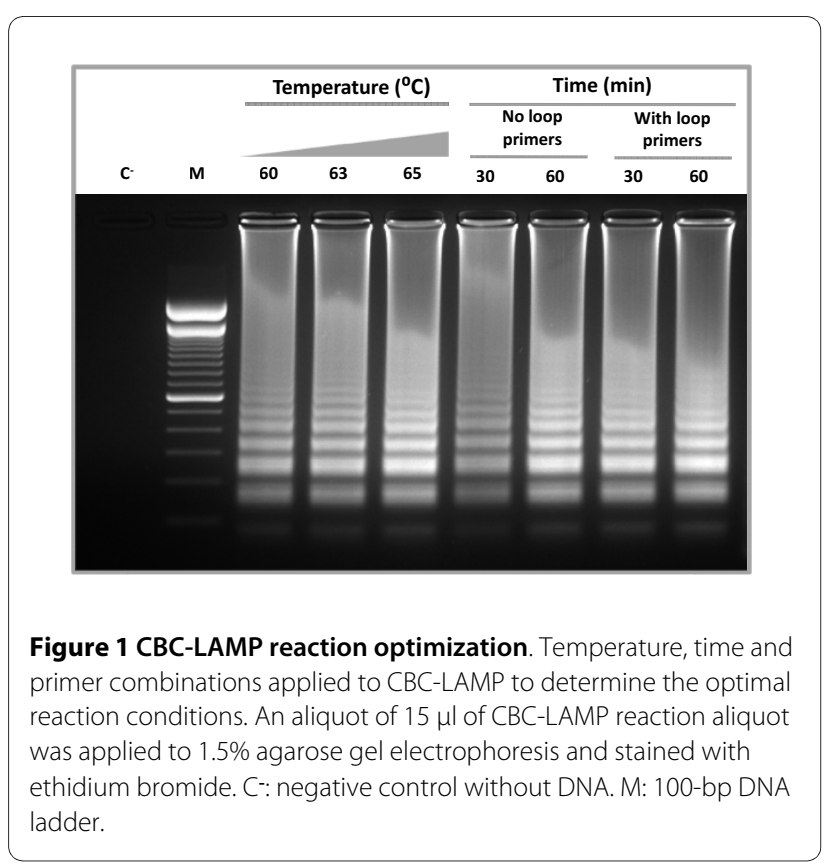

in this assay could require special attention in order to avoid final product contamination, a common setback in DNA-based diagnostics.

Specificity studies found no cross reaction with citrus and other plant pathogens, due to the fact that LAMP recognizes several sites in the template, improving specificity over conventional methods such as PCR [9]. Furthermore, a negative result was obtained with Xanthomonas citri pv. citrumelo, a closely related, non

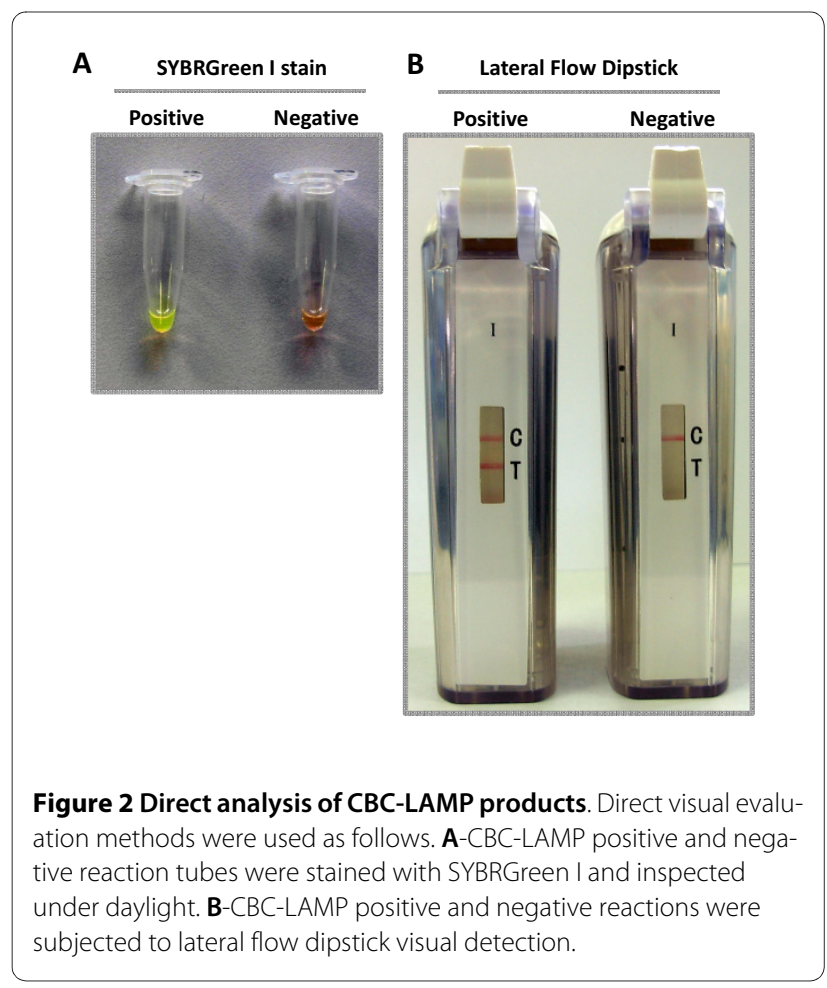


Table 2: CBC-LAMP assay sensitivity from pure DNA

\begin{tabular}{|c|c|c|c|c|c|c|c|c|c|}
\hline \multirow[t]{2}{*}{ Detection method } & \multicolumn{9}{|c|}{ Purified Xanthomonas citri subsp. citri DNA } \\
\hline & $100 \mathrm{ng}$ & $10 \mathrm{ng}$ & $1 \mathrm{ng}$ & $100 \mathrm{pg}$ & $10 \mathrm{pg}$ & $1 \mathrm{pg}$ & $100 \mathrm{fg}$ & $10 \mathrm{fg}$ & $1 \mathrm{fg}$ \\
\hline Gel & + & + & + & + & + & + & + & + & - \\
\hline LFD & + & + & + & + & + & + & + & + & - \\
\hline SYBRGreen & + & + & + & + & + & + & Nc & Nc & - \\
\hline
\end{tabular}

For each dilution the CBC-LAMP reaction was performed in triplicate. Gel: gel electrophoresis. LFD: lateral flow dipstick.+: Positive reaction.:Negative reaction. $\mathrm{Nc}$ : The colour developed in the test tube was not clearly distinguishable between a positive or negative reaction.

canker inducing Xanthomonas, ethiological agent of Citrus Bacterial Spot. This is concurrent with the fact that no $p t h A$ homolog has been found in this bacterium [6].

A BLAST search using as a query the target sequence of CBC-LAMP shows high identity with different CBCcausing Xanthomonas strains. Because pthA belongs to a family of Xanthomonas avirulence-pathogenicity genes, some grade of identity is found with other Xanthomonas spp., however as this xanthomonads do not attack citrus, this should not be a problem in diagnosing and identifying $\mathrm{CBC}$, as discussed by Cubero and Graham in a previous study [6]. Positive reaction was obtained in all Xanthomonas citri subsp, citri type A strains tested, comprising reference strains and field isolates from Argentina and other countries. Interestingly the strain $A^{*}$, a variant of the A strains from southwest Asia [4] is also recognized by the assay. Furthermore, CBC-LAMP was effective in the detection of type $B$ and $C$ strains; these results and the positive results obtained with field samples from lemon and orange confirm the robustness of the method here described for diagnosis of Citrus Bacterial Canker whatever the infecting variant is.

The DNA extraction method using Chelex allowed a fast and efficient DNA extraction from citrus plants infected with $X c c$ as described previously [4]. This method of sample preparation can be useful to shorten the time required in sample processing and in reducing the need for equipment. Amplicon detection by visual methods proved to be as sensitive as the gel in the case of lateral flow dipstick, but much faster and convenient. In the case of detection by adding SYBRGreen, when working with low concentrations of DNA the difference between positive and negative samples were not clear, this evidence a loss of sensitivity using the SYBRGreen detection method. Indeed we found the detection of the amplicon more robust using the lateral flow dipstick methodology as compared to the use of SYBRGreen.

The selected optimal conditions for amplification according to the experiments were $65^{\circ} \mathrm{C}$ for 30 minutes and with the addition of loop primers, which accelerated

Table 3: CBC-LAMP assay sensitivity from cultured cells and infected tissue

\begin{tabular}{|c|c|c|c|c|c|c|}
\hline Strain & $\begin{array}{l}\text { Specimen } \\
\text { source }\end{array}$ & Detection method & & $\begin{array}{l}\text { CFU pe } \\
\text { (10-fold }\end{array}$ & $\begin{array}{l}\text { on } \\
\text { ns) }\end{array}$ & \\
\hline \multirow[t]{4}{*}{ X. citri pv. citri } & Pure culture & & 395.3 & 37.6 & 5.2 & 0.7 \\
\hline & & Gel & + & + & + & - \\
\hline & & LFD & + & + & + & - \\
\hline & & SYBRGreen & + & + & + & - \\
\hline \multirow[t]{4}{*}{ X. citri pv. citri } & Infected tissue & & 248.4 & 18.7 & 3.3 & 0.2 \\
\hline & & Gel & + & + & - & - \\
\hline & & LFD & + & + & - & - \\
\hline & & SYBRGreen & + & + & - & - \\
\hline
\end{tabular}

For each dilution the CBC-LAMP reaction was performed in triplicate. Gel: gel electrophoresis. LFD: lateral flow dipstick. ${ }^{+}$: Positive reaction.: Negative reaction. 
Table 4: Strains of Citrus pathogenic Xanthomonas used to evaluate the CBC-LAMP assay

\begin{tabular}{|c|c|c|c|c|c|c|c|c|}
\hline \multirow[t]{2}{*}{ Species } & \multirow[t]{2}{*}{ Strain (s) } & \multicolumn{3}{|l|}{ Origin } & \multirow[t]{2}{*}{ CBC type } & \multicolumn{3}{|c|}{ Detection Method } \\
\hline & & Host & Place & Country & & Gel & LFD & S G \\
\hline \multirow{20}{*}{$\begin{array}{l}\text { Xanthomonas citri subsp. } \\
\text { citri }\end{array}$} & XC1CE & Tangerine & Concordia, Entre Rios & Argentina & A & + & + & + \\
\hline & XC2COE & Orange & Colon, Entre Rios & Argentina & A & + & + & + \\
\hline & ХСЗАМ-1, ХСЗАМ-2 & Lemon & Apostoles, Misiones & Argentina & A & + & + & + \\
\hline & XC4PM & Grapefruit & Posadas, Misiones & Argentina & A & + & + & + \\
\hline & XC5LF-1, XC5LF-2 & Grapefruit & Las Lomitas & Argentina & $A$ & + & + & + \\
\hline & XC7ETS-1, XC7ETS-2 & Orange & El Tabacal, Salta & Argentina & $A$ & + & + & + \\
\hline & XC8SPB-1, XC8SPB-2 & Orange & $\begin{array}{l}\text { San Pedro, Buenos } \\
\text { Aires }\end{array}$ & Argentina & A & + & + & + \\
\hline & ХС9САТ -1, ХС9САТ-2 & Orange & Catamarca & Argentina & A & + & + & + \\
\hline & XC10BVC -1, XC10BVC -2 & Lemon & Bella Vista, Corrientes & Argentina & $A$ & + & + & + \\
\hline & $\begin{array}{l}\text { XC10BVC }-3, \text { XC10BVC }-4, \\
\text { XC10BVC }-5\end{array}$ & Orange & Bella Vista, Corrientes & Argentina & A & + & + & + \\
\hline & XC10BVC -6, XC10BVC -7 & Grapefruit & Bella Vista, Corrientes & Argentina & $A$ & + & + & + \\
\hline & XC10BVC-8 & Tangerine & Bella Vista, Corrientes & Argentina & A & + & + & + \\
\hline & $\begin{array}{l}\text { XС6FT-1, ХC6FT-2, ХСТ2, } \\
\text { ХСТ3, ХСТ7, ХСТ9, ХСТ18, } \\
\text { ХСТ22, ХСТ31, ХСТ33, } \\
\text { ХСТ42 }\end{array}$ & Lemon Leave & Tucumán & Argentina & A & + & + & + \\
\hline & $\begin{array}{l}\text { ХСТ1, ХСТ17, ХСТ19, } \\
\text { ХСТ21, ХCT28, ХСТ29, }\end{array}$ & Lemon Fruit & Tucumán & Argentina & A & + & + & + \\
\hline & XCT44 & Tangerine Leave & Tucumán & Argentina & A & + & + & + \\
\hline & 306 (sequenced strain) & -- & -- & Brazil & A & + & + & + \\
\hline & 625 & -- & Aratiba, Sao Paulo & Brazil & $A$ & + & + & + \\
\hline & 1637 & -- & Embaúba, Sao Paulo & Brazil & A & + & + & + \\
\hline & 1740 & -- & -- & China & A & + & + & + \\
\hline & 1801 & -- & -- & Oman & $A^{*}$ & + & + & + \\
\hline \multirow{2}{*}{$\begin{array}{l}\text { Xanthomonas fuscans } \\
\text { subsp. Aurantifolii }\end{array}$} & B832 & -- & -- & Argentina & B & + & + & + \\
\hline & 382,1473 & -- & -- & Brazil & $C$ & + & + & + \\
\hline $\begin{array}{l}\text { Xanthomonas } \\
\text { axonopodis pv. Citrumelo }\end{array}$ & 1925 & -- & -- & USA & -- & - & - & - \\
\hline
\end{tabular}

For each isolate CBC-LAMP reaction was performed in triplicate. When available, detailed data about the place of origin and type of sample is included. Gel: gel electrophoresis. LFD: lateral flow dipstick. SG: SYBRGreen.+: Positive reaction.: Negative reaction.

the reaction by hybridization to the stem loops as described previously [10]. The combination of an isothermal amplification reaction followed by a visual detection method allows the detection of this pathogen with a speed not reported so far. The time it takes to perform the test using the lateral flow dipstick is approximately 45 min including the detection of the amplification product, without DNA preparation. This speed of detection coupled with the ability to be conducted in the field can be very important in plant protection programs for citrus producers and importer countries.

\section{Conclusions}

Considering the data from the loop-mediated isothermal amplification assay combined with the lateral flow dipstick device, we conclude that the technique is specific, reliable, sensitive, fast and represents a powerful diagnostic tool for CBC. The CBC-LAMP assay requires only a simple water bath, which makes this technique suitable as 
a field diagnosis tool in locations where more complex laboratory equipment is not available.

\section{Methods}

\section{Bacterial strains}

Xanthomonas citri subsp. citri strain 306 [34] was the reference strain used in this study; in addition, field isolates of Xcc from several geographical origins and different pathotypes were tested. The strains used in this work belong to the strain collection of the Dr. Canteros' laboratory at Instituto Nacional de Tecnología Agropecuaria (INTA), Bella Vista, Corrientes, Argentina. All the strains were propagated on their specific medium at $28^{\circ} \mathrm{C}$.

\section{Infected Plant Tissue}

For sensitivity tests, we used C. limón cv. Eureka leaves artificially inoculated with $X c c$ strain 306 as described previously [35]. Lemon and orange field samples were collected from citrus orchards in Tucumán province in Argentina from plants positives for $\mathrm{CBC}$.

\section{DNA extraction}

For sensitivity with pure DNA and specificity assays, DNA was extracted using the Wizard Genomic DNA purification Kit, Promega, Madison, WI, USA, according the manufacturer instructions. DNA obtained from cultured bacteria and infected tissue were purified using Chelex 100 resin, Biorad, Hercules, CA, USA, as described previously [4].

\section{LAMP reaction}

Oligonucleotide LAMP primers were designed according to the published sequence of PthA4 gene from Xcc [GenBank: XACb0065] using the program Primer Explorer version 4 (Net Laboratory, Tokyo, Japan) targeting the 5'end region of the gene (Fig. 3) which generated the primers XCC-F3, XCC-B3, XCC-FIP and XCC-BIP (Table 5). In addition a set of two Loop primers, XCC-LF and XCCLB was generated for reaction acceleration (Table 5). LAMP assay was performed using a thermal dry block with a $0.5-\mathrm{mL}$ PCR tube holder. Several reaction conditions were assayed, including different temperature, time
(Fig. 1), and primer concentrations (data not shown). The final LAMP conditions comprised 40 pmol each of primers XCC-FIP and XCC-BIP, 5 pmol each of outer primers XCC-F3 and XCC-B3, 20 pmol each of loop primers XCC-LF and XCC-LB, $8 \mathrm{U}$ of Bst DNA polymerase, 4.5 $\mathrm{mM} \mathrm{MgSO}_{4}, 1.4 \mathrm{mM}$ of dNTP mix, $20 \mathrm{mM}$ Tris- $\mathrm{HCl}(\mathrm{pH}$ 8.8), $10 \mathrm{mM} \mathrm{KCl}, 10 \mathrm{mM}\left(\mathrm{NH}_{4}\right)_{2} \mathrm{SO}_{4}, 0.1 \%$ Triton X-100 and $1.6 \mathrm{M}$ betaine, in a final volume of $25 \mu \mathrm{L}$ containing the template. This mixture was incubated at $65^{\circ} \mathrm{C}$ for 30 minutes.

\section{Analysis of LAMP products}

The amplified products were subjected to electrophoresis at $100 \mathrm{~V}$ for 50 minutes on a $1.5 \%$ agarose gel, followed by ethidium bromide staining. To confirm the specificity of the product some bands were cut and sequenced (data not shown). The sequences obtained were used as queries to perform BLAST searches [36] in order to confirm identity.

\section{Direct analysis of LAMP products}

For direct analysis of LAMP products, generic LFD strips (Type I BEST ${ }^{\mathrm{m} \mathrm{m}}$ cassette, Biohelix Co, Beverly, MA, USA) were used. These strips are capable to detect an amplicon that is dual labelled with biotin and fluorescein. For this purpose we used 5'-biotin-labelled XCC-FIP primers and 5'-fluorescein-labelled XCC-BIP primers in the amplification reactions. The labelled oligonucleotides were purchased from Integrated DNA Technologies ${ }^{\text {Tw }}$ requesting HPLC purification. After amplification reaction, the reaction tube is inserted in the detection chamber; the dual tagged amplicon is automatically mixed with the detection buffer, and directed by capillary flow to the strip. The amplicon is detected in the test zone $(\mathrm{T})$ of the cassette whereas the control zone $(C)$ serves as a control for the flow function. The complete detection process takes about 10 minutes. More information is available in the manufacturer web site http://www.biohelix.com/products/Type I \& Type II Cassettes.asp.

The inspection for amplification was also performed through observation of colour change after addition of 1 $\mu \mathrm{L}$ of a 1:1000 dilution of SYBRGreen dye to the reaction

Table 5: Sequences of primers used for CBC-LAMP assay

\begin{tabular}{llll}
\hline Primer Name & Type & Sequence (5'-3') & Length \\
\hline XCC-F3 & F3 & GGTGGATCTACGCACGC & 17 mer \\
XCC-B3 & B3 & GCTGCGATCATGTCCTGAT & 19 mer \\
XCC-FIP & FIP (F1C+F2) & GGTGCTGCGCCACTGTCGAA - GCTACAGCCAGCAGCAACA & 39 mer \\
XCC-BIP & BIP (B1C+B2) & GCACTGGTCGGCCATGGGTA - GCGACGGTCCCTAACG & 36 mer \\
XCC-LF & LF & AACCTTCGGTTGATCTTCTCC & 22 mer \\
XCC-LB & LB & TTACACACGCGCACATCGT & 19 mer \\
\hline
\end{tabular}


${ }_{449}^{\text {CCGCGCAGGT GGATCTACGC ACGCTCGGCT ACAGCCAGCA GCAACAGGAG }}$

$$
\begin{aligned}
& \text { AAGATCAAAC CGAAGGTTCG TTCGACAGTG GCGCAGCACC ACGAGGCACT } \\
& \frac{\text { G1 }}{\text { GGTCGGCCAT GGGTTTACACACGCGCACAT CGITGCGCTC AGCCAACACC }} \\
& \text { CG1c } \\
& \frac{\text { CGGCAGTT AGGGACCGTC GCTGTCAAGT ATCAGGACAT GATCGCAGCG }}{\text { B2C }}
\end{aligned}
$$

Figure 3 Localization of target sequences used for primer construction. Target sequences used for LAMP primer design are underlined and shadowed. The figure shows a portion of $p t h A$ gene from $X c c$ 449 nucleotides downstream from the start codon.

tube. In the case of positive amplification the original orange color of the dye turns to green which can be examined in daylight.

\section{Sensitivity of LAMP}

In the sensitivity assay from pure DNA, $100 \mathrm{ng}$ of $X c c$ DNA was 10-fold diluted and used as template for LAMP amplifications. For sensitivity assay from cultured cells, 10 -fold dilutions of $X c c$ liquid culture were prepared, then a 4- $\mu \mathrm{L}$ aliquot from the dilutions were used for plating and colonies enumeration and, after DNA purification processing, 4- $\mu \mathrm{L}$ aliquots of dilutions were used as DNA template. In the assay for sensitivity from infected tissue, artificially-infected citrus leaves were used as starting material for the same procedure mentioned above.

\section{Additional material}

Additional file 1 Fig. S1 CBC-LAMP performance with field samples.

Field samples of Lemon and Orange was collected and analyzed by CBCLAMP. LFD: lateral flow dipstick. SG: SYBRGreen. GEL: gel electrophoresis.

\section{Authors' contributions}

LAR designed the experiments, performed the experimental work and drafted the manuscript; MRM and APC contributed to coordinate the study and to draft the manuscript; AMDA isolated the DNA sample from Candidatus Liberibacter asiaticus used for specificity tests and critically revised the manuscript; AAV participated in the analysis and interpretation of the data and prepared the final version of the manuscript. All authors read and approved the final version of the manuscript

\section{Acknowledgements}

We thank Dr. Blanca Canteros for providing us the field isolates of Xcc used in this study. We appreciate Drs. Kamal Bouarab and Mohamed El Oirdi for kindly providing Botrytis cinerea DNA. MRM, APC and AAV are Career Investigators of Consejo Nacional de Investigaciones Científicas y Técnicas (CONICET), Argentina. This work was supported by Agencia de Promoción Científica y Tecnológica of Argentina. We thank tree anonymous reviewers for the invaluable help.

\section{Author Details}

IInstituto de Ciencia y Tecnología Dr. Cesar Milstein, Fundación Pablo Cassará, Consejo Nacional de Investigaciones Científicas y Técnicas, Saladillo 2468 , Ciudad de Buenos Aires, Argentina, Instituto de Biología Molecular de Rosario, Departamento de Microbiología, Facultad de Ciencias, Bioquímicas y Farmacéuticas, Universidad Nacional de Rosario, Rosario, Argentina, 3 Sección de Biotecnología de la Estación Experimental Agroindustrial Obispo
Colombres. UA-INSIBIO, Consejo Nacional de Investigaciones Científicas y Técnicas, Universidad Nacional de Tucumán, Las Talitas, Tucumán, Argentina and ${ }^{4} E$ mbrapa Recursos Genéticos e Biotecnologia and Centro APTA Citros Sylvio Moreira, Brasilia, AC, Cordeiropolis, Sao Paulo, Brazil

Received: 16 December 2009 Accepted: 18 June 2010 Published: 18 June 2010

\section{References}

1. Moreira LM, de Souza RF, Almeida NF, Setubal JC, Oliveira JC, Furlan LR, Ferro JA, da Silva AC: Comparative genomics analyses of citrusassociated bacteria. Annu Rev Phytopathol 2004, 42:163-184.

2. Moreira LM, Almeida NF, Potnis N, Digiampietri LA, Adi SS, Bortolossi JC, da Silva AC, da Silva AM, de Moraes FE, de Oliveira JC, et al:: Novel insights into the genomic basis of citrus canker based on the genome sequences of two strains of Xanthomonas fuscans subsp. aurantifolii. BMC Genomics 11(1):238.

3. Gottwald TR, Hughes G, Graham JH, Sun X, Riley T: The citrus canker epidemic in Florida: the scientific basis of regulatory eradication policy for an invasive species. Phytopathology 2001, 91(1):30-34.

4. Mavrodieva V, Levy L, Gabriel DW: Improved sampling methods for realtime polymerase chain reaction diagnosis of citrus canker from field samples. Phytopathology 2004, 94(1):61-68.

5. Hartung JS, Daniel JF, Pruvost OP: Detection of Xanthomonas campestris pv. citri by the polymerase chain reaction method. Appl Environ Microbiol 1993, 59(4):1143-1148.

6. Cubero J, Graham JH: Genetic relationship among worldwide strains of Xanthomonas causing canker in citrus species and design of new primers for their identification by PCR. Appl Environ Microbiol 2002, 68(3):1257-1264.

7. Coletta-Filho HD, Takita MA, Souza AA, Neto JR, Destefano SA, Hartung JS, Machado MA: Primers based on the rpf gene region provide improved detection of Xanthomonas axonopodis pv. citri in naturally and artificially infected citrus plants. J App/ Microbio/ 2006, 100(2):279-285.

8. Cubero J, Graham JH: Quantitative real-time polymerase chain reaction for bacterial enumeration and allelic discrimination to differentiate xanthomonas strains on citrus. Phytopathology 2005, 95(11):1333-1340.

9. Notomi T, Okayama H, Masubuchi H, Yonekawa T, Watanabe K, Amino N, Hase T: Loop-mediated isothermal amplification of DNA. Nucleic Acids Res 2000, 28(12):E63.

10. Nagamine K, Hase T, Notomi T: Accelerated reaction by loop-mediated isothermal amplification using loop primers. Mol Cell Probes 2002, 16(3):223-229.

11. Kaneko H, Kawana T, Fukushima E, Suzutani T: Tolerance of loopmediated isothermal amplification to a culture medium and biological substances. J Biochem Biophys Methods 2007, 70(3):499-501.

12. Andrade TP, Lightner DV: Development of a method for the detection of infectious myonecrosis virus by reverse-transcription loop-mediated isothermal amplification and nucleic acid lateral flow hybrid assay. $J$ Fish Dis 2009, 32(11):911-924.

13. Ding WC, Chen J, Shi YH, Lu XJ, Li MY: Rapid and sensitive detection of infectious spleen and kidney necrosis virus by loop-mediated isothermal amplification combined with a lateral flow dipstick. Arch Virol 155(3):385-389.

14. James HE, Ebert K, McGonigle R, Reid SM, Boonham N, Tomlinson JA Hutchings GH, Denyer M, Oura CA, Dukes JP, et al:: Detection of African swine fever virus by loop-mediated isothermal amplification. J Virol Methods 164(1-2):68-74

15. Jaroenram W, Kiatpathomchai W, Flegel TW: Rapid and sensitive detection of white spot syndrome virus by loop-mediated isothermal amplification combined with a lateral flow dipstick. Mol Cell Probes 2009, 23(2):65-70

16. Kiatpathomchai W, Jaroenram W, Arunrut N, Jitrapakdee S, Flegel TW: Shrimp Taura syndrome virus detection by reverse transcription loopmediated isothermal amplification combined with a lateral flow dipstick. J Virol Methods 2008, 153(2):214-217.

17. Nimitphak T, Kiatpathomchai W, Flegel TW: Shrimp hepatopancreatic parvovirus detection by combining loop-mediated isothermal amplification with a lateral flow dipstick. J Virol Methods 2008, 154(12):56-60.

18. Njiru ZK, Mikosza AS, Armstrong T, Enyaru JC, Ndung'u JM, Thompson AR: Loop-Mediated Isothermal Amplification (LAMP) Method for Rapid 
Detection of Trypanosoma brucei rhodesiense. PLoS Neg/ Trop Dis 2008, 2(1):e147.

19. Saleh M, Soliman H, El-Matbouli M: Loop-mediated isothermal amplification as an emerging technology for detection of Yersinia ruckeri the causative agent of enteric red mouth disease in fish. $B M C$ Vet Res 2008, 4:31.

20. Parida M, Horioke K, Ishida H, Dash PK, Saxena P, Jana AM, Islam MA, Inoue S, Hosaka N, Morita K: Rapid detection and differentiation of dengue virus serotypes by a real-time reverse transcription-loop-mediated isothermal amplification assay. J Clin Microbiol 2005, 43(6):2895-2903.

21. Shiotani H, Fujikawa T, Ishihara H, Tsuyumu S, Ozaki K: A pthA homolog from Xanthomonas axonopodis pv. citri responsible for host-specific suppression of virulence. J Bacterio/ 2007, 189(8):3271-3279.

22. Al-Saadi A, Reddy JD, Duan YP, Brunings AM, Yuan Q, Gabriel DW: All five host-range variants of Xanthomonas citri carry one pthA homolog with 17.5 repeats that determines pathogenicity on citrus, but none determine host-range variation. Mol Plant Microbe Interact 2007, 20(8):934-943.

23. Fujikawa T, Ishihara H, Leach JE, Tsuyumu S: Suppression of defense response in plants by the avrBs3/pthA gene family of Xanthomonas spp. Mol Plant Microbe Interact 2006, 19(3):342-349.

24. Yang B, White FF: Diverse members of the AvrBs3/PthA family of type III effectors are major virulence determinants in bacterial blight disease of rice. Mol Plant Microbe Interact 2004, 17(11):1192-1200.

25. Swarup S, Yang Y, Kingsley MT, Gabriel DW: An Xanthomonas citri pathogenicity gene, pthA, pleiotropically encodes gratuitous avirulence on nonhosts. Mol Plant Microbe Interact 1992, 5(3):204-213.

26. Adhikari BR, Pandey BD, Ghimire P, Shrestha B, Khadka M, Yoda T, Suzuki Y: Loop-mediated isothermal amplification (LAMP) for the direct detection of human pulmonary infections with environmental (nontuberculosis) mycobacteria. Jpn J Infect Dis 2009, 62(3):212-214

27. Alhassan A, Thekisoe OM, Yokoyama N, Inoue N, Motloang MY, Mbati PA, Yin H, Katayama Y, Anzai T, Sugimoto C, et al:: Development of loopmediated isothermal amplification (LAMP) method for diagnosis of equine piroplasmosis. Vet Parasitol 2007, 143(2):155-160.

28. Andrade TP, Lightner DV: Development of a method for the detection of infectious myonecrosis virus by reverse-transcription loop-mediated isothermal amplification and nucleic acid lateral flow hybrid assay. $J$ Fish Dis 2009, 32(11):911-24.

29. Aryan E, Makvandi M, Farajzadeh A, Huygen K, Bifani P, Mousavi SL, Fateh A, Jelodar A, Gouya MM, Romano M: A novel and more sensitive loopmediated isothermal amplification assay targeting IS6110 for detection of Mycobacterium tuberculosis complex. Microbiol Res 2009, 165(3):211-220

30. Boldbaatar B, Inoue S, Sugiura N, Noguchi A, Orbina JR, Demetria C, Miranda ME, Yamada A: Rapid detection of rabies virus by reverse transcription loop-mediated isothermal amplification. Jpn J Infect Dis 2009, 62(3):187-191.

31. Chen HT, Zhang J, Sun DH, Ma LN, Liu XT, Cai XP, Liu YS: Development of reverse transcription loop-mediated isothermal amplification for rapid detection of $\mathrm{H} 9$ avian influenza virus. J Virol Methods 2008 151(2):200-203

32. Curtis KA, Rudolph DL, Owen SM: Rapid detection of HIV-1 by reversetranscription, loop-mediated isothermal amplification (RT-LAMP). J Virol Methods 2008, 151(2):264-270.

33. Fall J, Chakraborty G, Kono T, Maeda M, Itami T, Sakai M: Establishment of loop-mediated isothermal amplification method (LAMP) for the detection of Vibrio nigripulchritudo in shrimp. FEMS Microbiol Lett 2008, 288(2):171-177.

34. da Silva AC, Ferro JA, Reinach FC, Farah CS, Furlan LR, Quaggio RB, Monteiro-Vitorello CB, Van Sluys MA, Almeida NF, Alves LM, et al: Comparison of the genomes of two Xanthomonas pathogens with differing host specificities. Nature 2002, 417(6887):459-463.

35. Rigano LA, Siciliano F, Enrique R, Sendin L, Filippone P, Torres PS, Questa J, Dow JM, Castagnaro AP, Vojnov AA, et al:: Biofilm formation, epiphytic fitness, and canker development in Xanthomonas axonopodis pv. citri. Mol Plant Microbe Interact 2007, 20(10):1222-1230.

36. Altschul SF, Gish W, Miller W, Myers EW, Lipman DJ: Basic local alignment search tool. J Mol Biol 1990, 215(3):403-410. doi: 10.1186/1471-2180-10-176

Cite this article as: Rigano et al., Rapid and sensitive detection of Citrus Bacterial Canker by loop-mediated isothermal amplification combined with simple visual evaluation methods BMC Microbiology 2010, 10:176

\section{Submit your next manuscript to BioMed Centra and take full advantage of:}

- Convenient online submission

- Thorough peer review

- No space constraints or color figure charges

- Immediate publication on acceptance

- Inclusion in PubMed, CAS, Scopus and Google Scholar

- Research which is freely available for redistribution
C Biomed Central 